\title{
Crushed Limestone Dust Valorization for Eco Friendly non Fired Wall Tiles
}

\author{
Ubolrat Wangrakdiskul, Kannika Benjaratthapong and Meatra Jongtrakulsiri \\ Department of Production Engineering, Faculty of Engineering, King Mongkut's University of Technology North Bangkok, Bangkok 10800 , \\ Thailand
}

\begin{abstract}
Utilizing crushed limestone dust; the by-product of crushing limestone plant for producing non-fired wall tiles is the objective of this research. The main raw materials of non- fired wall tiles consist of laterite soil, fluvial sand and Portland cement. The crushed limestone dust has been used as the substitute material of non-fired wall tiles for enhancing their bending strength. In this experiment, four groups of formulas have been constructed. Firstly, crushed limestone dust has been mixed into the basic formula for substitution of laterite soil. Secondly, crushed limestone dust has been used for substitution to river soil of the basic formula. Thirdly, it has been substituted to Portland cement in the basic formula. Finally, the best formulas of the first three groups has been selected and mixed up to make the new formulas. After mixing the raw materials of selected formula, forming specimens by uni-axial pressing at 100 bar has been performed. Then, they have been aged for 1 week at the room temperature. After that, testing the specimens' properties has been carried out. They are bending strength and water absorption which comparing with Thailand Industrial Standard (TIS) 614-2529. The experimental results show that adding the crushed limestone dust to the basic composition has an effect on the bending strength and water absorption. The compositions of the best formula are laterite soil $55 \%$, fluvial sand $7.5 \%$, Portland cement $22.5 \%$, and crushed limestone dust $15 \%$. It gives the bending strength by $2.32 \mathrm{MPa}$, water absorption $3.20 \%$. The water absorption property can pass the TIS standard, but bending strength could not pass. The estimated cost of raw materials is $0.09065 \mathrm{THB} / 100 \mathrm{~g}$.
\end{abstract}

\section{Introduction}

Crushed limestone is one of products for many construction uses including: Portland cement concrete aggregate, asphalt pavement (hot mix and warm mix) aggregate, asphalt surface treatments, road base, structural fill, railroad ballast, rip rap, and drainage and erosion control. In 2015, there are many limestone crushing plants in Thailand which are 314 plants. The total capacity is approximately $166 \times 10^{6} \mathrm{MT} /$ year [1]. During the crushing process, by products such as crushed limestone dust having diameter less than $3 \mathrm{~mm}$ have been generated approximately $14.5 \%$ of total production. Its selling price is $260 \mathrm{THB} /$ ton [2]. However they can be utilized as the substitute material for replacement in fluvial sand of concrete product. For used as value added material, limestone crushed dust has been studied by many researchers. Galetakis and Raka have mixed limestone dust with Portland cement for producing artificial stone. The results indicate that limestone can be used and give the acceptable compressive strength [3]. Utilization of limestone dust for brick making has been investigated in Egypt, finding of this research shows that $87 \%$ of limestone dust can be replaced on cement in the composition of bricks [4]. Fathi has studied about the effects of limestone crushed dust on the compressive strength and workability of concrete. This research indicated that limestone dust can be replaced on the natural sand in concrete composition with higher compressive strength [5].

Turgut and Halil have investigated the physical and mechanical properties of brick samples with wood sawdust wastes (WSW) and limestone powder wastes (LPW). The experiment shows that the WSW-LPW combination provides results which are of potential to be used in the production of lighter and economical new brick material [6]. Turgut has studied the utilization of different grades of wood sawdust wastes (WSW) and limestone powder wastes (LPW) for cement composites. The results indicated the high energy absorption capacity, reduced the unit weight dramatically and introduce a smoother surface compared to the current bricks in the market [7]. In 2008, Turgut investigated both physical and mechanical properties of samples containing limestone powder wastes (LPW) - waste glass powder (WGP) combinations for producing as new building brick material. An experimental approach to develop a new brick material including mainly LPW, a small quantity of Portland cement and WGP is presented. The WGP used in LPW remarkably improves the compressive strength, flexural strength, modulus of elasticity, abrasion resistance, F-T resistance, and thermal conductivity of LPW brick samples produced in this study [8]. Furthermore in 2013, Turgut also studied about the LPW and cotton waste material for replacement in artificial limestone composites. The energy conservation in 
buildings by using limestone powder waste and cotton waste composites having low thermal conductivity can reduce energy requirements [9]. Wangrakdiskul et al. have studied about non-fired wall tiles by replacement spent bleaching earth (SBE) in the basic formula having basic materials; laterite soil, fluvial sand, and Portland cement [10].

Most of previous researches mentioned above have focused on cement bricks production. Some research has used wastes from palm oil industry for non-fired wall tiles [10]. However, studying on utilizing limestone dust for non-fired wall tiles production is just not investigated. Therefore, this study aims to utilize crushed limestone dust in non-fired wall tiles. The experimental procedure will be described in the next section.

\section{Experimental procedure}

\subsection{Materials}

Basic materials used in this study consist of laterite soil, fluvial sand and Portland cement type I. The by-products material; crushed limestone dust from limestone crushing plant has been utilized for replacement on basic materials. Crushed limestone dust with diameter less than $3 \mathrm{~mm}$ has been used. The mixture proportions of basic formula for non-fired wall tiles have been provided from Wangrakdiskul, et al in 2008[11]. Mixing formulas of this experiment will be classified in following section.

\subsection{Method of experimental research}

All of materials as mentioned above have been prepared as the procedure illustrated in Fig. 1. It consists of 8 steps. In the $3^{\text {rd }}$ step, formulas of varying the proportion of materials have been constructed which consist of 18 formulas (see Table 1, 2, and 3). The based formula No. $1 \_0$ is obtained from Wangrakdiskul, et al [11]. Thirty pieces of specimens are performed for each formula. It could be explained in the following section.

Table 1. Composition formulas of varying \%CLD by weight in laterite soil (Group 1).

\begin{tabular}{|c|c|c|c|c|}
\hline No & $\begin{array}{c}\text { \%Fluvial } \\
\text { Sand }\end{array}$ & $\begin{array}{c}\text { \%Portland } \\
\text { Cement }\end{array}$ & $\begin{array}{c}\text { \%Laterite } \\
\text { Soil }\end{array}$ & $\begin{array}{c}\text { \%Crushed } \\
\text { Limestone } \\
\text { Dust (CLD) }\end{array}$ \\
\hline $1 \_0$ & 15 & 22.50 & 62.5 & 0 \\
\hline $1 \_1$ & 15 & 22.50 & 57.5 & 5 \\
\hline $1 \_2$ & 15 & 22.50 & 52.5 & 10 \\
\hline 1_3 & 15 & 22.50 & 47.5 & 15 \\
\hline $1 \_4$ & 15 & 22.50 & 42.5 & 20 \\
\hline $1 \_5$ & 15 & 22.50 & 37.5 & 25 \\
\hline $1 \_6$ & 15 & 22.50 & 32.5 & 30 \\
\hline $1 \_7$ & 15 & 22.50 & 27.5 & 35 \\
\hline $1 \_8$ & 15 & 22.50 & 22.5 & 40 \\
\hline $1 \_9$ & 15 & 22.50 & 17.5 & 45 \\
\hline $1 \_10$ & 15 & 22.50 & 12.5 & 50 \\
\hline $1 \_11$ & 15 & 22.50 & 7.5 & 55 \\
\hline $1 \_12$ & 15 & 22.50 & 2.5 & 60 \\
\hline
\end{tabular}

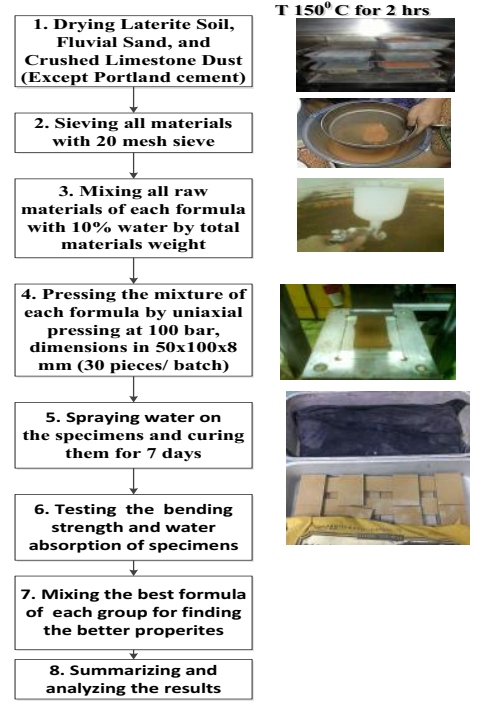

Figure 1.The experimental procedure.

According to Table 1, 2, and 3, notice that formula No 10 is used as the basic formula of all groups for this experiment. Testing of bending strength and water absorption as indicated on step 6, the specimens have been performed in accordance with TIS 614-1986 and calculated the results by the formulas as expressed in Eq. 1 and Eq. 2.

$$
\mathrm{B}=3 \mathrm{PL}
$$

where

$\mathrm{B}=$ Bending strength $(\mathrm{MPa})$

$\mathrm{P}=$ The maximum load applied to break a specimen (N)

$\mathrm{L}=$ Span length of beam supporting specimen $(\mathrm{mm})$

$\mathrm{b}=$ Width of specimen $(\mathrm{mm})$

$\mathrm{d}=$ Thickness of specimen $(\mathrm{mm})$

$$
\% \text { Water absorption }=(\mathrm{WW}-\mathrm{Wd}) * 100
$$

where

$\mathrm{Ww}=$ Wet weight of specimen after placed in boiling water for five hours then soaked at room temperature water for 24 hours $(\mathrm{g})$

$\mathrm{Wd}=$ Dry weight of specimen $(\mathrm{g})$

After the properties of all formulas in three groups have been analysed and summarized by statistical analysis, the formulas of each group providing the high strength have been selected and then mixed with each other for producing the new formulas. The results will be described in the following section.

Table 2. Composition formulas of varying \% CLD by weight in fluvial sand (Group 2).

\begin{tabular}{|c|c|c|c|c|} 
No & $\begin{array}{c}\text { \%Fluvial } \\
\text { Sand }\end{array}$ & $\begin{array}{c}\text { \%Portland } \\
\text { Cement }\end{array}$ & $\begin{array}{c}\text { \%Laterite } \\
\text { Soil }\end{array}$ & $\begin{array}{c}\text { \%Crushed } \\
\text { Limestone } \\
\text { Dust (CLD) }\end{array}$ \\
\hline $1 \_0$ & 15 & 22.5 & 62.5 & 0 \\
\hline $2 \_1$ & 10 & 22.5 & 62.5 & 5 \\
\hline $2 \_2$ & 5 & 22.5 & 62.5 & 10 \\
\hline $2 \_3$ & 0 & 22.5 & 62.5 & 15 \\
\hline
\end{tabular}


Table 3. Composition formulas of varying \%CLD by weight in Portland cement (Group 3).

\begin{tabular}{|c|c|c|c|c|}
\hline No & $\begin{array}{c}\text { \%Fluvial } \\
\text { Sand }\end{array}$ & $\begin{array}{l}\text { \%Portland } \\
\text { Cement }\end{array}$ & $\begin{array}{c}\text { \%Laterite } \\
\text { Soil }\end{array}$ & $\begin{array}{l}\text { \%Crushed } \\
\text { Limestone } \\
\text { Dust (CLD) }\end{array}$ \\
\hline $1 \_0$ & 15 & 22.5 & 62.5 & 0 \\
\hline 3_1 & 15 & 17.5 & 62.5 & 5 \\
\hline 3_2 & 15 & 12.5 & 62.5 & 10 \\
\hline 33 & 15 & 7.5 & 62.5 & 15 \\
\hline
\end{tabular}

\section{Results and discussion}

\subsection{Mechanical and Physical Properties of group}

\section{$1,2,3$ and 4 .}

The properties of each formula have been classified into three groups in accordance with the group's formula; group 1, 2 and 3 . They have been indicated in figure 2, 3 and 4.

According to fig 2, the results of replacement crushed limestone dust (CLD) to laterite soil have been illustrated. They can be summarized that the effect of CLD can enhance the bending strength. Obviously, the best formula that provides the highest bending strength is No.1_3. It consists of $15 \%$ of CLD. At the same time, \%water absorption of this group is varying from 3.57-5.87. The best formula for lowest \%water absorption is also No.1_3.

The results of replacement crushed limestone dust (CLD) to fluvial sand have been expressed in fig 3. The effects of CLD in fluvial sand can enhance the bending strength. The best formula that provides the highest bending strength is No.2_3. It consists of $15 \%$ of CLD, similarly the results of group 1 . However, \%water absorption of this group is higher than that of the basic formula No.1_0.

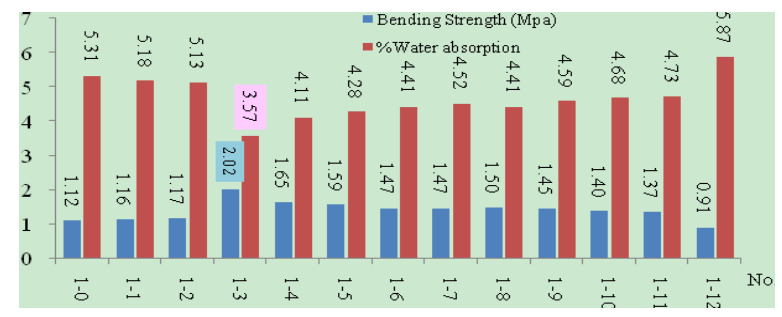

Figure 2. Bending strength and water absorption of group 1.

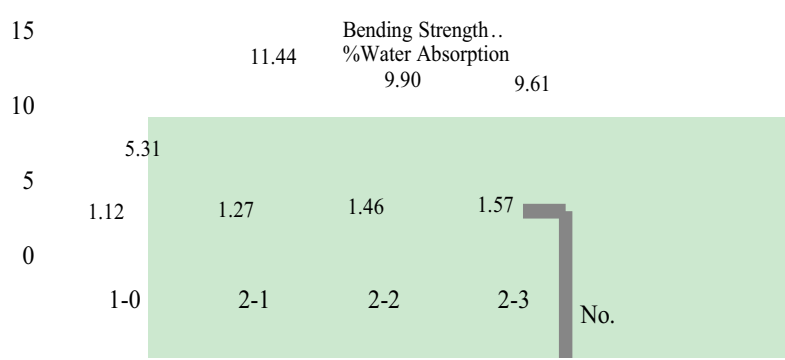

Figure 3. Bending strength and water absorption of group 2 .
The effects of replacement CLD in Portland cement have been expressed in fig 4 . As the increased of CLD of each formula, it gives the decreased of bending strength and increased of water absorption. The best formula of this group is No.3_1 which consists of 5\%CLD. However, when comparing with the results of other groups, this group has not been selected for further improvement. Due to, the composition of CLD of the best formula is only $5 \%$.

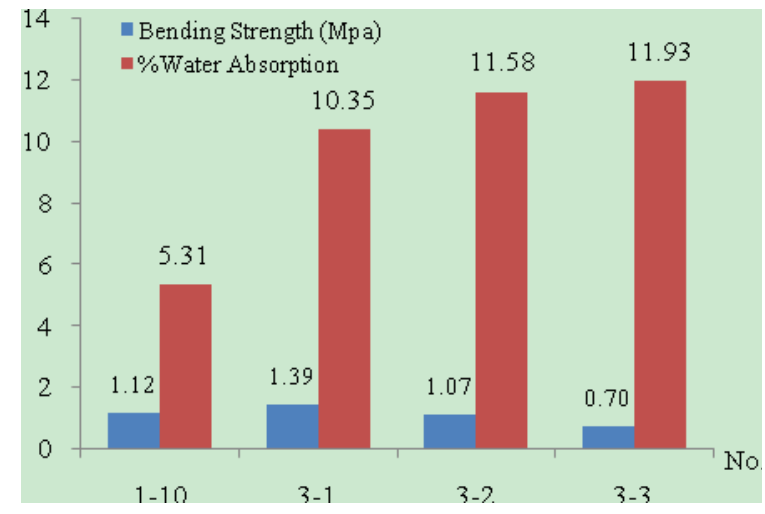

Figure 4. Bending strength and water absorption of group 3.

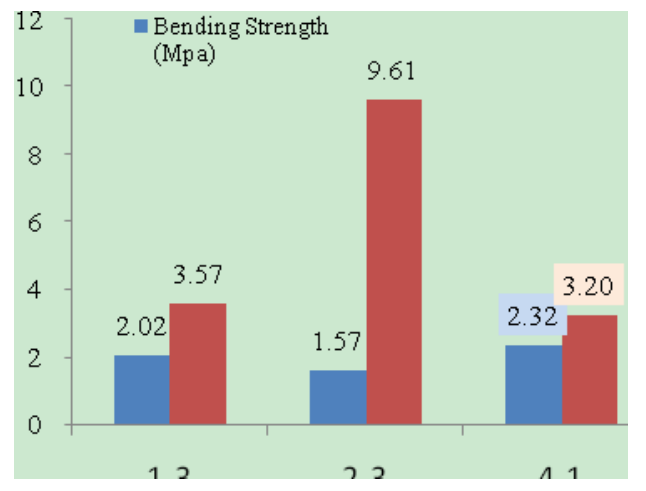

Figure 5. Bending strength and water absorption of group 4 mixing of the best formula from group 1 and 2 .

Table 4. Composition formulas of No.4_1 the average composition of each material.

\begin{tabular}{|c|c|c|c|c|}
\hline No & $\begin{array}{c}\text { \%Fluvial } \\
\text { Sand }\end{array}$ & $\begin{array}{c}\text { \%Portland } \\
\text { Cement }\end{array}$ & $\begin{array}{c}\text { \%Laterite } \\
\text { Soil }\end{array}$ & $\begin{array}{c}\text { \%Crushed } \\
\text { Limestone } \\
\text { Dust } \\
\text { (CLD) }\end{array}$ \\
\hline $1 \_3$ & 15 & 22.5 & 47.5 & 15 \\
\hline $2 \_3$ & 0 & 22.5 & 62.5 & 15 \\
\hline $4 \_1$ & 7.5 & 22.5 & 55 & 15 \\
\hline
\end{tabular}

Considering results of all three groups, the formula No.1_3 of group 1 and No.2_3 of group 2 have been selected for further investigated. Their compositions have been mixed to produce the new formula so called No.4_1. Its composition has been illustrated in table 4 .

Bending strength and \%water absorption of formula No.4_1 has been shown in fig 5. It can give the favorable properties, because the bending strength is higher than that of No.1_3 and No.2_3. Furthermore, its \%water absorption is lower than that both of them. 


\section{Statistical analysis}

For approving the results of this study, the experimental design has been conducted [12]. One way ANOVA has been employed for analyzing the effect of raw material replacement on the properties of each formula. P-values of hypothesis testing with a 0.05 significance level of the experiment are illustrated in Table 5.

Table 5. One way ANOVA test with a 0.05 significance level of varying raw materials on physical properties of each formula group.

\begin{tabular}{|c|c|c|}
\hline Group & $\begin{array}{c}\text { Bending } \\
\text { Strength }\end{array}$ & \%Water absorption \\
\hline 1 & 0.000 & 0.000 \\
\hline 2 & 0.003 & 0.037 \\
\hline 3 & 0.000 & 0.006 \\
\hline 4 & 0.000 & 0.000 \\
\hline
\end{tabular}

According to table 5, p-values of bending strength and water absorption for all experimental groups are less than 0.05 . This means that replacement of CLD waste into main raw materials has an effect on bending strength and water absorption. However, the appropriate composition has been selected by considering on high bending strength and low \%water absorption. In this study, formula No.4_1 is the most appropriate composition for more investigation.

\section{Conclusion}

As mentioned in the previous section, the best formula is No.4_1 with the highest bending strength and lowest water absorption. It can be concluded that CLD waste can fill up between the particles of laterite soil and of fluvial sand. Therefore, the water absorption is less than that of basic formula. Materials costs of all materials per $1000 \mathrm{~g}$. and the best formula are 0.09065 THB (\$0.00269 USD) per $100 \mathrm{~g}$. of the test specimen which are shown in table 6 and 7 , respectively.

Table 6. Costs of materials used for this study.

\begin{tabular}{|l|c|}
\hline Raw Material & THB/ 1000 g \\
\hline Fluvial Sand & 0.235 \\
\hline Portland Cement & 3 \\
\hline Laterite Soil & 0.318 \\
\hline CLD & 0.26 \\
\hline
\end{tabular}

Table 7. Materials costs of the best formula (No.4_1).

\begin{tabular}{|l|c|c|}
\hline \multirow{2}{*}{ Raw Material } & \% By weight & THB/ 100 g (piece) \\
\hline Fluvial Sand & 7.5 & 0.00176 \\
\hline Portland Cement & 22.5 & 0.06750 \\
\hline Laterite Soil & 55 & 0.01749 \\
\hline CLD & 15 & 0.00390 \\
\hline \multicolumn{2}{|c|}{ Total cost/pc } & $0.09065 \mathrm{THB}$ \\
\cline { 2 - 3 } & $\$ 0.00254 \mathrm{USD}$ \\
\hline
\end{tabular}

Note: $\$ 1 \mathrm{USD}=35.7 \mathrm{THB}$

Table 8. Physical properties of the best formula comparing with TIS 614-1986 standard.

\begin{tabular}{|l|c|c|}
\hline & $\begin{array}{c}\text { Bending Strength } \\
\text { (Mpa) }\end{array}$ & $\begin{array}{c}\text { \%Water } \\
\text { absorption }\end{array}$ \\
\hline $\begin{array}{l}\text { TIS 614-1986 } \\
\text { Standard }\end{array}$ & 20 & 6 \\
\hline Formula No.4_1 & 2.32 & 3.2 \\
\hline
\end{tabular}

As shown in Table 8, bending strength of the best formula is lower than that of to the TIS 614-1986 standard. However, its water absorption is approximately close that standard. Enhancement the bending strength should be further investigated. The first aspect is to study about extending the curing period of specimens from 7 days to 28 days [6]. In addition, the second aspect is to utilize the other alternative materials such as waste ash from boiler of palm oil mill industry. Because this material composition has the silica content which can be replaced in laterite soil and fluvial sand [13]. Furthermore, increasing the composition of Portland cement in the formula should be considered [10].

Although the appropriate formula could not achieve the TIS standard's bending strength. This product should be used as eco-friendly product utilizing the waste materials. In addition, it could be substitute the building material that needs not to be fired. In the future, if bending strength of products can meet TIS 614-1986, it can response the customers who want to use the ecofriendly products.

\section{References}

1. Department of Primary Industries and Mines, Ministry of Industry, Access on : June 2, 2015 http://www1.dpim.go.th/csh/cr.php

2. Sila Chairoen Company, Access on : June 5, 2015 https:/www.facebook.com/silachaicharoen?fref $=$ nf

3. M.Galetakis, S. Raka, Utilization of limestone dust for artificial stone production: an experimental approach, Minerals Engineering. 17, 355-7 (2004)

4. A.A. Mageeda, G.S. AbdelHaffez,Utilization of Limestone Dust in Brick Making, Journal of Engineering Sciences, Assiut University. 40, 3 913922 (2012)

5. I. S. Fathi, Effect of Using Crushed Limestone in Concrete Mixes as Fine Aggregate on Compressive Strength and Workability, International Conference on Civil, Biological and Environmental Engineering (CBEE-2014). Istanbul (Turkey) (2014)

6. P.Turgut, M. A. Halil, Limestone dust and wood sawdust as brick material, Building and Environment. 42, 3399-403 (2007)

7. P. Turgut, Cement composites with limestone dust and different grades of wood sawdust, Building and Environment. 42, 3399-3403 (2007) 
8. P. Turgut,Limestone dust and glass powder wastes as new brick material, Materials and Structures. 41, 805-813 (2008)

9. P. Turgut, Research into Artificial Limestone Composites with Cotton Waste, Jordan Journal of Civil Engineering. 7, 1 126-131 (2013)

10. U. Wangrakdiskul, P. Khonkaew, T. Wongchareonsin, Use of the Spent Bleaching Earth from Palm Oil Industry in Non Fired Wall Tiles, The 3rd International Symposium on the Fusion Technologies 2014 (ISFT2014), Jeonju, S.KOREA, 30 July-3 August. (2014)

11. U. Wangrakdiskul, T. Kleepung, P. Srihakham, The Possibility Study of Using Laterite Clay, Soil and
Cement Interlocking for Non Fired Wall Tiles, Proceedings of Industrial Engineering Network Conference 2008. 20th-22ndOctober. pp1015.Songkhla. Thailand. (2008)

12. M.J. Anderson, S.L. Kraber, Keys to successful designed experiments. Tech. Rep., Stat-Ease, Inc., Minneapolis, MN (2002). [Online]. Available: http://www.statease.com/pubs/doe-keys.pdf

13. V. Sata, C. Jaturapitakkul, K. Kiattikomol, Utilization of Palm Oil Fuel Ash in High-Strength Concrete, Journal of Mater 